UDC 351.77(477)

DOI https://doi.org/10.32782/klj/2021.1.11

\author{
Voroniatnikov O. O., \\ Doctor of Science of Law, \\ Chief Inspector of the International Police Cooperation Department \\ of the National Police of Ukraine \\ Voronyatnikov@gmail.com
}

\author{
Kostiuk T. O., \\ Doctor of Public Administration, associate professor, \\ Senior Research Fellow of Scientific Research Laboratory of \\ Internationalization of Higher Education, \\ Borys Grinchenko Kyiv University \\ t.kostiuk@kubg.edu.ua
}

\title{
SYNERGY OF ADMINISTRATIVE, JURIDICAL, AND INSTITUTIONAL POLICIES FOR SUCCESSFUL IMPLEMENTATION OF TRANSBORDER COOPERATION IN HIGHER EDUCATION IN UKRAINE
}

\begin{abstract}
Due to the fact that Ukraine is at the same time the country of origin, destination and transit of migrants, the territory of various scales, characters and vectors migratory flows, it appears difficult to ensure the overall sound State regulation in the field of migration. The solution requires a comprehensive and systematic approach. Among all the factors influencing the public administration of migration processes, its legal background, the issue of the impact of university education on the attraction of foreign capital (in various forms) for the progress of the nation is of the highest interest in this survey.

The academic publishing on public administration traditionally emphasizes the theories or mechanisms of management and governance. Significant part of the researchers is considering topical issues by sectors of the public administration system. But nowadays societal development needs multilevel solution with engagement of different fields providing a synergy on administrative, managerial and institutional potential of the State. Equally, sound public administration in one field will boost some other fields and it underlines the necessity of adequate qualification, competences and experience of the policymakers and public administrators. Indeed, in the given paper we provide analysis of interdependence of the migration and educational processes with close consideration of common impact on the development of other sectors of societal life. It is proven that there is a causal link between the educational processes, lawmaking and public administration activity in framework of the migration monitoring and governance. The synergy of the state bodies' efforts shapes its image, attractiveness for foreigners and, thus, the economic growth. Thus, the cross-disciplinary analysis of a complex set of forces led to the fact that adequate migration policy is needed in order to ensure effectiveness of the internationalization policy, to revive national economics, to preserve the managerial potential of the State.
\end{abstract}

Key words: migration process, public administration, higher education, internationalization of higher education, Ukraine.

Воронятников О. О., Костюк Т. О. Синергія адміністративної, юридичної та інституційної політики для успішного впровадження транскордонного співробітництва у вищій освіті в Україні

Анотація. Через те, що Україна одночасно $є$ країною походження, призначення та транзиту мігрантів, територією різного масштабу, характером та переносом міграційних потоків, представляється важким забезпечити загальне надійне державне регулювання у сфері міграції. Рішення вимагає комплексного та систематичного підходу. Серед усіх факторів, що впливають на державне управління міграційними процесами, головним $€$ його правове підгрунтя. Питання впливу університетської освіти на залучення іноземного капіталу (у різних формах) для прогресу нації представляє найбільший інтерес у цьому опитуванні.

В академічних публікаціях про державне управління традиційно наголошується на теоріях або механізмах управління та управління. Значна частина дослідників розглядає актуальні питання за секторами системи державного управління. Але в наш час суспільний розвиток потребує багаторівневого вирішення із залученням різних галузей, що забезпечують синергію адміністративного, управлінського та інституційного 
потенціалу держави. Подібним чином надійне державне управління в одній галузі сприятиме підвищенню деяких інших галузей, і це підкреслює необхідність належної кваліфікації, компетенції та досвіду політиків та державних адміністраторів. Справді, у цій роботі ми проводимо аналіз взаємозалежності міграційних та освітніх процесів з пильним розглядом спільного впливу на розвиток інших секторів суспільного життя. Доведено, що існує причинно-наслідковий зв'язок між освітніми процесами, законотворчістю та діяльністю державного управління в рамках моніторингу та управління міграцією. Синергія зусиль державних органів формує їх імідж, привабливість для іноземців i, отже, економічне зростання. Таким чином, міждисциплінарний аналіз складної сукупності сил призвів до того, що необхідна адекватна міграційна політика для забезпечення ефективності політики інтернаціоналізації, відродження національної економіки, збереження управлінського потенціалу держави.

Ключові слова: міграційний процуес, державне управління, вищза освіта, інтернаціоналізація вищзӧ освіти, Украӥна.

Introduction. In the context of the global intensification of migration processes, which are nowadays mostly regarded as a threat to the national security, the need to improve migration legislation is increasing in order to ensure the effective use of the positive migration potential for development, minimization of its negative effects, and the safeguarding of the rights and freedoms of migrants and the local citizens. On the other hand, the free cross-border movement of goods, people and services has greatly revitalized the country's economic and financial sector, stimulating the continual increase of its export potential.

Many researchers dealing with migration issues focus on legal and political issues do not take into account that a public administration sector of higher education can become the boost able to greatly influence the formation of a state migration policy.

The aim of the given research is to clarify the causal link between the educational processes, lawmaking and public administration activity in framework of the migration monitoring and governance. The synergy of the state regulations in the abovementioned fields shapes its image, attractiveness for foreigners and, thus, the economic growth, reduce of criminal rate, facilitation in the transfer of knowledge and skills and vice versa. Thus, the cross-disciplinary analysis is applied to reach the aim and to examine the interdependent processes involving a complex set of forces.

The theoretical-methodological underpinnings. The cross-disciplinary approach to studying the issues of mutual influence and interdependence of migration and educational processes in the context of effective public administration expands the empirical database of previous studies on these issues.
The survey was conducted on the basis of documents and analytical reports, statistical information of the Organization for Economic Cooperation and Development (OECD), UNESCO and the State bodies of Ukraine disclosing the core issues of migration. They reveal not only statistical differences in migration models, but also a variety of theoretical debates trying to understand the international migration.

Similarly, the most interesting for us in the context of the given research are papers on the students'mobility. Thus, C. Madge with co-authors (Madge C., Raghuram P., Noxolo P. (2009), 34-45) summarizes visions existing in the scientific discourse and divides them into three broad areas. The first relates to the analysis of the mobility of foreign students through the objective of government agencies of migration processes; the second examines students'migration as part of overall mobility and IHE, while the third one focuses on purely educational issues that arise in the context of students' mobility. Moreover, attention was paid to the historical analysis of migration, namely the study of the constitutive role of a foreign student contingent for the development of higher education and national projects in the twentieth century.

Despite such an empirical background, many researchers of migration processes generally do not mention the students going to study in other countries in this category. But we support thesis of close correlation of migration process and the students' mobility in framework of IHE.

Studies of the internationalization of higher education in the aspect of incoming credit or degree academic mobility which is the most closely related to the migration processes have been explored in the works of W. Taichler (2011), B. Wachter (2011), G. De Wit (2012), I. Ferentz (2011), M. Parey 
(2011), F. Waldinger and K. Janson (2007). The most completely the question of academic mobility, in our opinion, is disclosed in the writings of W. Taichler's works. His studies make it possible to comprehend all aspects of international academic mobility at macro and meso levels, in a global and European dimension. B. Wachter (2011) investigated the mobility in two levels: the incoming and outgoing student mobility in Europe, and the mobility, carried out within theEuropean educational space, and from the outside into the European educational space. Further study was also undertaken of the issue of comparative analysis of student mobility within Erasmus+ initiatives and unrelated academic mobility. W. Taichler, B. Wachter, I. Ferentz (eds.) altogether with L. Rambli, S. Burger and J. Lansendorf (2011) are the authors of the fundamental scientific work based on the study "Mapping mobility in higher education in Europe", where, in addition to a detailed analysis of student credit and step-by-step international Mobility, Academic International Mobility, their advantages, threats and disadvantages, the authors overviewed the EU national mobility policies in higher education.

The attempt to solve the research problem belongs to well-known Ukrainian scientists M. Holovatyi, T. Kostiuk, V. Kolpakova, O. Kuzmenko, T. Zhizhko, D. Sviridenko and others. Thus, M. Holovatyi besides a deep analysis of contemporary political processes and the development of an effective policy of a strong social state on the basis of social interaction, paid much attention to the phenomenon of multiculturalism (M. Holovatyi, 2015). Multiculturalism and interethnic tolerance are important factors for the State mature behavior in different fields, particularly via internationalization of higher education to the intergovernmental co-working. To reach success in the aforementioned activities there is a need to overcome three key problems of human existence (Holovatyi, 2014). The first of them means foundation and further development of statehood. This problem is the most challenging and vexed in the postSoviet, «post-Socialist» area, for the stated that, like Ukraine, emerged recently on the world map. This overlook comes down to the destiny of more significant processes of transformation in the sphere of economics, politics and social life.
Economic transformation (reform) is critical here. At last the third problem, that of spiritual societal development.

T. Kostiuk has conducted an overall analysis of the IHE regulation at institutional and national levels and has concluded that the State as the main provider of the educational serviceshas to implement the national IHE strategy which among other will make all HEIs to stimulate incoming mobility (Kostiuk, 2016). This type of migration process is the most profitable, but its activation often depends on external factors that the university cannot influence: the general reputation and attractiveness of the host country (for example, the presence of world-renowned higher educational institutions, the climate, prominent historical monuments of culture, language policy etc.), the political situation, the level of higher education, confirmed by the international ratings of universities, etc. From time to time there is a rotation of demand for incoming/ outgoing mobility. At times, institutional reforms, the introduction of new programs or quality requirements reduce the external demand for programs and institutions of the country, that is, their initial mobility. Conversely, the political processes in the native country (the revolution, the manifestations of xenophobia, etc.) or economic benefits (subsidizing foreigners, beneficial financial conditions for the training of specialists from the host party due to its interest in existing training programs in the field of knowledge) can be a catalyst for activation and development incoming mobility (Kostiuk, 2018).

T. Zhyzhko (2010) analyzed mobility in terms of the Bologna process. D. Svyrydenko (2014) considers academic mobility in the discourse of freedom, distinguishing "mobility out", "mobility in", "true" and "false" academic mobility.

Discussion. The analysis of the scientific papers shows the categorical uncertainty. Thus, they talk about migration in a generic sense and migration with the aim to get educational services in another country is usually called mobility. The notional differentiation could make no sense as a whole but it is noteworthy in the context of higher education.

Close consideration shows that the European researchers more often use the category "mobility". Mobility highlights the movement associated with migration, not with departure, arrival to settlements and related prospects. In most cases, 
it is also noted that mobility involves a shorter term of relocation abroad and a high probability of return, as in framework of the European Union program Erasmus + . Longer trips to study abroad for the completion of the educational qualification level, 3-4 years, fall entirely within the statistical definition of international migration (often due to trips for a period of one year and longer), with a more open probability of returning to the country of origin. Using the students' mobility term, this terminology dilemma seems to be removed, although in general it is often deciphered as "international student mobility" relative to the duration of student mobility, which also emphasizes terminological uncertainty.

As the Ministry of Science and Education of Ukraine certifies, more than 75,000 students from 154 different countries study in Ukraine today. And every year the number of visiting students tends to increase. Top 10 countries of origin of foreign students are: India (almost 15,000), Morocco (7,300), Azerbaijan (6,200), Turkmenistan (5,000), Nigeria $(3,500)$, Egypt $(3,400)$, Turkey $(3,200)$, China $(2,700)$, Israel $(2,400)$ and Georgia (2,400). According to the data of Ministry of Education and Science of Ukraine, the number of foreign students in Ukraine for the years 2008-2014 has increased from 42 to 69 thousand people, and the amount of funds received to the state budget from payment for their training increased for more than UAH $500 \mathrm{mln}$. At the present stage, there is an increase in students from the countries of the former USSR, in particular from the countries of Central Asia. The most significant increase in the indicators was observed for students from Azerbaijan (an increase of 5 times), Turkmenistan (an increase of more than 3 times), Uzbekistan (an increase of 3 times); there is also an increase in education from Kyrgyzstan, Tajikistan, and Kazakhstan. At the same time, the number of students from the Middle East countries decreased significantly, primarily due to security issues, an unstable political situation and military actions in Eastern Ukraine, which undoubtedly is a loss of Ukraine's traditional markets for educational services. A small percentage of students from developed countries of Europe and the world is due to the same factors and insufficiently high quotations of domestic higher education institutions in international ratings, which determines the level of education quality, and the unsatisfactory level of implementation of educational programs in a foreign language.

This trend has a controversial assessment from the point of view of public administration. On the one hand, it is positive due to the financial benefit, but at the same time it poses a potential threat to the development of the education system of Ukraine, since the contingent of foreign students of significantly lower "quality" has increased at times, which does not allow raising the "standard" requirements as to the quality offered to foreigners education, and to its applicants.

Adaptation of foreign students in terms of their everyday life and leisure is another one task for the public administration; it needs special attention and control of the state in order to prevent the growth of crime and the subsequent stereotyped distorted perception of foreigners, based on the current geography of origin. There are numerous cultural centers, associations of ethnic representatives which become not only ethnic cells and meeting points, but also active participants in the political process in Ukraine.

That is, the public administration of the migration related processes either via IHE or in other forms in Ukraine should take into account all its advantages and risk-forming potential for constructing a rational model of adaptation of international experience under the realities of our state and direct the main efforts to develop the infrastructure for attracting the best foreigners which will create a positive image of the state in the world.

Regarding the state policy of export-oriented educational potential of Ukraine, there is also a number of organizational and legal issues concerning the foreign students' arrival, stay and general control and support during their studies and extracurricular activity in Ukraine. In order to invite foreign students or specialists the state bodies must first adopt laws and provide the appropriate infrastructure for active life and leisure. Unfortunately, there are many problems with that, even English language possession in Ukraine is poor enough for the foreigners to get served in it in public places. It never adds attractiveness for the State whose preliminary task is to successfully compete on the world market of elite education and investments attractiveness. 
Actually, even the quality of teaching in English is not often satisfactory; moreover, the educational courses are not exclusive to the degree to be competitive in the modern international educational environment. In addition, in Ukraine there is no proper normative basis for the implementation of double diploma programs, there often appear complications with the recognition of Ukrainian diplomas abroad. The bureaucratic scarcity of the authorities responsible for attracting, issuing visas and permitting documents for entry and study in Ukraine are the reason for the dropout of a significant number of applicants to obtain higher education here. The problems often arise at the stage of obtaining visa, then - with permission for temporary residence in Ukraine. This shifts accent of importance and monopoly from the State onto the intermediaries, influencing managerial potential of the State.

Additionally, there is a task to the State policymakers to adoptlaws regulating the foreigners' employment, it will boost national economics. to mention that foreign students do not have the right to work while studying in Ukraine, which makes it impossible to obtain additional official income to improve their financial position. Often, this problem leads to the search for illegal ways of enrichment, and, consequently, the growing criminal statistics involving foreign students: organizational irregularities not only lead to a decrease in the number of foreign contingents in the national HEIs of Ukraine, but also to significant economic losses, lack of funds to the state budget and a deterioration of the image of the state in the world educational market.

Conclusion. It is impossible to provide sound State policy in some separate fields as all the sectors of public administration and its functional mechanisms are interrelated. Thus, the adequate lawmaking guarantees overall benefits for internal development and external image.

The paper deals with the fact that sound State policy in migration regulation issues makes favor to different aspects of social life: 1. to higher education, as it simplifies the process of arrival into country and safeguards the State tools to monitor and to regulate the quality and quantity of incoming contingent; due to the external demand to the educational services it stimulate national HEIs to guarantee supply of the educational services and their quality; 2. for economics as foreigners bring investment, funds, grant programs, stimulate transfer of knowledge and technologies; 3. for national security because adequate juridical background for the foreigners' rights, constant improvement of legal consolidation of the entrance and stay in the country, work and study conditions, infrastructure and access to the ethnical communities suppose low criminal statistics with the migrants; 4. for internal and external State policy. For instance, the foreign students do not have the right to work while studying in Ukraine, which makes it impossible to obtain additional official income to improve their financial situation. Often, this problem leads to the search for illegal ways of enrichment, and, consequently, the growing criminal statistics involving foreign students. Organizational irregularities not only lead to a decrease in the number of foreign contingents in the national higher educational institutions of Ukraine, but also to significant economic losses, lack of funds to the state budget and a deterioration of the image of the state in the world educational market.

Besides, if to talk about higher education and particularly about the IHE process, the state policy must seek to increase the horizontal incoming mobility by reducing the vertical incoming mobility (the terms proposed by W. Taichler (1997)). In the first case, students come from an academically and economically less developed country or institution to a more successful country and institution in order to improve the quality of their skills and capacities. In the second case, students move between countries and institutions of a similar academic level for the purpose of their own development, experience in the multicultural space. However, the relative balance of power should be maintained, since, as a rule, in the case of vertical academic mobility, it is a degree mobility which often ends by immigration to the recipient country, while in the case of horizontal academic mobility it is a credit mobility previewing short stay in the country.

Consequently, the issues of political, economic, legal nature and social protection are topical and of high importance. In order to avoid the risks and negative consequences of any processes in the field of higher education in Ukraine, it is recommended to develop and adopt the Strategy of Internationalization of Higher Education 
and permanently adopt the legislation according to the world practice.

Summary. The academic publishing on public administration traditionally emphasizes the theories or mechanisms of management and governance. Significant part of the researchers is considering topical issues by sectors of the public administration system. But nowadays societal development needs multilevel solution with engagement of different fields providing a synergy on administrative, managerial and institutional potential of the State. Equally, sound public administration in one field will boost some other fields and it underlines the necessity of adequate qualification, competences and experience of the policymakers and public administrators.
Indeed, in the given paper we provide analysis of interdependence of the migration and educational processes with close consideration of common impact on the development of other sectors of societal life. It is proven that there is a causal link between the educational processes, lawmaking and public administration activity in framework of the migration monitoring and governance. The synergy of the state bodies' efforts shapes its image, attractiveness for foreigners and, thus, the economic growth. Thus, the cross-disciplinary analysis of a complex set of forces led to the fact that adequate migration policy is needed in order to ensure effectiveness of the internationalization policy, to revive national economics, to preserve the managerial potential of the State.

\section{REFERENCES}

1. De Wit, H. (2012). Student mobility between Europe and the rest of the world: Trends, issues and challenges. In A. Curaj, P. Scott, L. Vlasceanu \& L Wilson (Eds.), European higher education at the cross roads: Between the Bologna Process and national reforms (pp. 431-439). Dordrecht: Springer.

2. Findlay A.M., King R., Smith F.M., Geddes A., Skeldon R. (2012). World class? An investigation of globalization, difference and international student mobility. Transactions of the Institute of British Geographers, 37, 118-131.

3. Holovatyi, M. (2014). Multiculturalism as a means of nations and countries interethnic unity achieving. Economic Annals-XXI, 11-12, 15-18.

4. Holovatyi, M. (2015). The state and society: The conceptual foundations and social interaction in the context of formation and functioning of states. Economic Annals-XXI, 9-10, 4-8.

5. Kostiuk, T. (2016). Higher Education to Export: Requirements of Internationalization to the Public Administration System. Public Administration: Improvement and Development, 1. URL: http://www.dy.nayka. com.ua/?op=1\&z=1296.

6. Kostiuk, T. (2016). International academic mobility: current and perspective issues in the field and public administration. Public Administration: Improvement and Development, 10. URL: http://www.dy.nayka.com. ua/ op $=1 \& z=1298$.

7. Kostiuk, T. (2018). Differentiation of approaches to the determination of student mobility/ migration phenomenon in educational and scientific discourse. The State and the regions, 4(64), 82-86.

8. Madge C., Raghuram P., Noxolo P. (2009). Engaged pedagogy and responsibility: a postcolonial analysis of international students. Geoforum, 40, 34-45.

9. Mosneaga A, Winther L. (2013). Emerging talents? International students before and after their career start in Denmark. Population, Space and Place: this issue.

10. Parey M., Waldinger F. (2011). Studying abroad and the effect on international labour market mobility: evidence from the introduction of Erasmus. The Economic Journal, 121, 194-222.

11. Teichler, U. (1997). The British involvement in European higher education programmes: Findings of evaluation studies on Erasmus, Human Capital and Mobility and Tempus. In The Thirtieth Anniversary Seminars (pp. 39-64). London: Society for Research into Higher Education.

12. Teichler, U., Ferencz, I. \& Wächter, B. (Eds.) (2011). Mapping mobility in higher education in Europe. Volumes $1 \& 2$. Bonn: Deutscher Akademischer Austauschdienst.

13. Teichler, U. \& Janson, K. (2007). The professional value of temporary study in another European country: Employment and work of former Erasmus students. Journal of Studies in International Education, 11 (3/4), 486-495.

14. Teichler, U. The impact of temporary study abroad. URL: http://www.eurosla.org/monographs/EM04/ Teichler.pdf.

15. Svyrydenko, D. (2014). Academic Mobility: The Answer to the Challenges of Globalization. Kyiv. 2014.

16. Zyzhko, T. (2010). Academic mobility as an objective condition for the development of university education. Bulletin of the Institute for the Development of the Child. Series: Philosophy. Pedagogy. Psychology: Collection of scientific works, 10, 6-10. 